\title{
Supply Chain Risk Analysis on Vending Machine Products (Study Case in XYZ Company)
}

\author{
Puti Sinansari $^{1}$, Nugroho Priyo Negoro ${ }^{1}$, Muhammad Muadz Abdillah ${ }^{1}$ \\ ${ }^{1}$ Department of Business Management, Institut Teknologi Sepuluh Nopember, Surabaya \\ puti.sinansari707@gmail.com
}

\section{Received: 11/11/2020. \\ Reviewed: $10 / 02 / 2021$ \\ Published: $31 / 07 / 2021$.}

Copyright $\odot 2021$ by the author (et al) and Jurnal Sosial Humaniora (JSH)

${ }^{*}$ This work is licensed under the Creative Commons Attribution International License (CC BY4.0). http://creativecommons.org/licenses/by/4.0/

\section{Subject Area: Ekonomi (Economic)}

\begin{abstract}
The development of business and technology ecosystems demands industry to always make adjustments. Supply chain changes become one that is certain to happen. This change process allows the company to manage and minimize risks. Therefore, it is necessary to apply good risk management to minimize the impact of risk. As one of the vending machine service companies in Indonesia, PT XYZ has a long supply chain, covering the production process, assembling, shipping and customer service. This research aims to identify risk events and risk agents and determine the priority of risk agents in the vending machine service company at PT XYZ. The design of this research uses the first stage House of Risk method to identify risk events and risk agents as well as determining the highest risk agent. Then the highest risk agent is ranked inPareto diagram to determine risk agent priority. The prospect of this research will be an overview of the risks that may arise in the vending machine servicecompany in Indonesia.
\end{abstract}

Keywords: House of Risk, Supply Chain Management, Risk Management, Pareto, Vending Machine

\section{Introduction/Background}

The vending machine industry in Indonesia is still in the basic stage where the number of vending machines in Indonesia lagged considerably compared to the number of vending machines in other countries such as Japan and Singapore. Although vending machine is not common in Indonesia, but the megapolitan city such as Jakarta, starting to use vending machine for electric trains ticket and also beverage in some train stations. For the next 10 years, this vending machine will help a lot to reduce working load for simple jobs such as selling simple stuff like food, beverage, and tickets.

Nowadays vending machine is based on online technology system, which is very dependable on internet network service. When the internet network disconnected there will be a big problem such as the delay payment and will make the vending machine cannot be used. Another problem is there are only few professional technicians who can handle the vending-machine system, this make the obstacle for vending machine industry is getting higher. Therefore, the company requires knowledge of good risk management.

XYZ Company, or PT. XYZ, is one of the biggest vending machine companies in Indonesia, based in Jakarta. The operational risk has been a big issue for this company because the demand for this vending 
machine is rising up, but the operational dan maintenance in every unit is getting harder every day. Some examples of risks in business processes that arise such as product design inconsistency, hardware and software installation errors, delays in delivery of products to company partners, and fault services to consumers. There are two crucial parts in vending machine products, software, and hardware. These parts hold important stuff about the maintenance part of the machine, because PT XYZ not only selling the product but also giving a maintenance service for its client. Seeing so many problems and risk in operational and business part, PT XYZ certainly demands that the company to have a good supply chain risk management, so that it can minimize the risk in their supply chain.

This research will identify and analyze the risks that may occur in the supply chain of PT XYZ through the House of Risk. House of Risk is a method focused on formulating preventive strategies, reduction, and risk handling that can result in more than one risk. Hopefully this study can have impact not only for PT XYZ, but also other company in vending machine industry to make a better in risk management in supply chain section. Another purpose of this research is to see the risks that may arise in the supply chain of a vending machine business, as well as to create a priority risk resolution. The results of this research are expected to be a guideline and advice for PT XYZ and similar companies to face problems related to the risk in supply chain.

\section{Literature Review}

\section{Supply Chain Risk Management}

Supply chain is a various activity in order to acquire raw goods, then processing into products in the process, then further processing into finished goods and continued distribution to the consumer (Arif, 2018). While in supply chain we also need to manage the flow from raw material into goods that can be sent to consumer, we call it as supply chain management. This management of supply chain is a coordinated system consisting of organizations, human resources, activities, information and other resources that collectively cooperate to move products or services in physical or virtual form from suppliers to consumers. From Pujawan \& Geraldin (2009), the goal of supply chain risk management is to reduce the likelihood of risk events as well as to increase resistance, because in supply chain is a very long chain and the possibility of risk during line is very high. From the sustainable business point of view, by focusing in supply chain risk management it will interference the arising possibility of internal and external risk that can happen (Fan \& Stevenson, 2018). Companies that can be able to manage risk well will pose better positions than their competitors. There are five stages to analyze in supply chain risk management (Oguzhan \& Erol, 2017):
1. Risk identification
2. Risk assessment
3. Risk evaluation
4. Risk mitigation
5. Monitoring and risk control 
After knowing about the supply chain management, we need to make a better plan to make the risk is measurable by following the management protocol Plan, Do, Check and Action. Supply Chain Operations Reference (SCOR) is a reference model in the process of referencing, proposing terminology and notation systems to describe a business process (Knolmayer, Mertens, Zeier, \& Dickersbach, 2009). According to Knolmayer et al. (2009) quoting from the Supply Chain Council, SCOR comprises of 5 process elements covering Plan, Source, Make, Deliver, and Return.

\section{House of Risk}

The House of risk method is designed as a tool for identifying, analyzing, risk evaluation and planning of risk management strategies in the supply chain. This method is the development of the Quality Function Deployment (QFD) method, in which the model uses the House of Quality (HOQ) to compile the mitigation action in dealing with potentially potential risks to the supply chain. HOR consists of two phases, namely the first phase is risk identification, and the second phase is risk management (Pujawan \& Geraldin, 2009). This research is more likely to lead to the first phase, i.e., Identification risk and cause risk that willresult in the priority rating of risk agent.

The step in doing HOR first stage is as follows:

1. Observe the process of supply chain in one object

2. Identify risk event $(E i)$ and risk agent $(A j)$ that can occur in each subprocess.

3. Calculation of risk impact severity variable or risk event (Ei), within 1-10 where 10 is a risk with verysevere impact; and assess the level of emergence risk agent (Aj), with a scale of 1-10 where 10 is frequently and always happen in the observation object.

4. Build correlation matrix between $E i$ and $A j$, namely Rij

5. Fill within this number $\{0,1,3,9\}$, where 0 : no correlation, 1: weak correlation, 3: moderate correlationdan 9: strong correlation

6. Formula of aggregate risk potential or ARP value of Aj used:

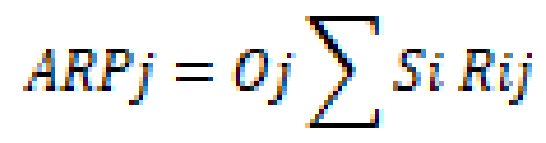

Description:

- $\quad$ ARPj $=$ Aggregate Risk Potential from causes of risk sources ( $j$ )

- $\quad \mathrm{Oj}=$ Possible risk agent $(\mathrm{j})$

- $\quad \mathrm{Si}=$ The magnitude of impact if risk (i) happens

- $\quad \mathrm{Rij}=$ Correlation between risk (i) with risk agent (j)

7. Rate the ARP of each Aj descending (decreases from the largest to the smallest)

8. Create pareto diagram of $\mathrm{Aj}(\mathrm{Aj}$ priority selection) 


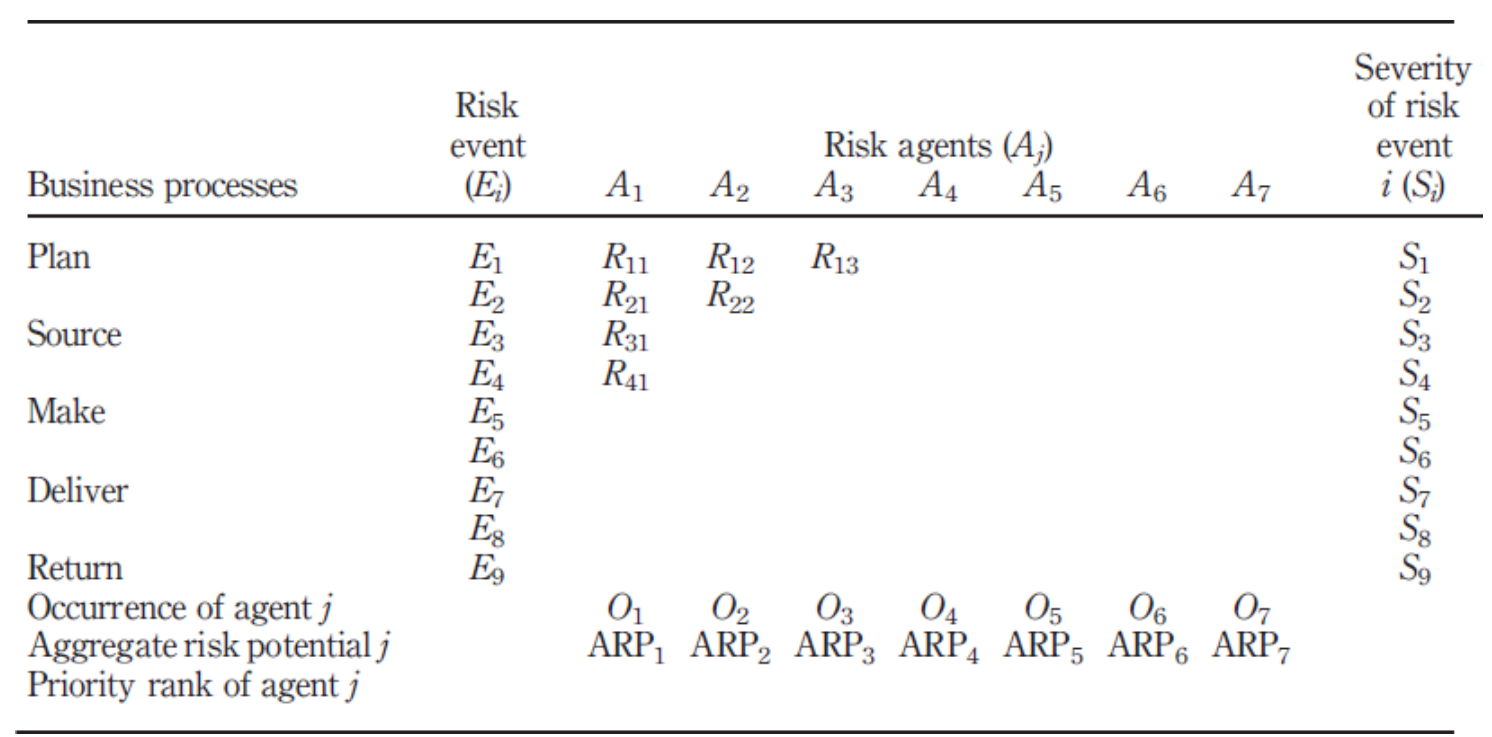

Source: (Pujawan \& Geraldin, 2009)

\section{Pareto Diagram}

The Pareto Diagram is a part of the Basic Seven Tools of Quality and visualize as bar graph that shows problems based on the order of the number of occurrences (Sokovic, pavletic, \& Fakin, 2005). The pareto 80/20 rule, also known as the Pareto Principle or law Pareto, states that a small number of causes (20\%) Responsible for the majority (80\%) of its effects. In various cases stated that there was a 20 percent defect that raises 80 percent problem (Lipovetsky, 2009). In terms of risk management when adhering to the Pareto theory $80 / 20,80$ percent of the risk impact is caused by 20 percent the cause of the risks. So in this research will try to search the $20 \%$ causes which make $80 \%$ risk impact for the company.

\section{Methodology}

The first phase of this study is using House of Risk (HOR) to implement in the entire businessprocess of supply chain PT XYZ. This method consists of 4 phases, which are:

A. Preparation Phase

This phase consists of formulating problems and objectives, by doing the research study from book literature and supply chain process business secondary data in the company, then mapping it into five business process namely, plan, source, make, deliver and return. Plan is a process where the supply chain is plan to send, while Source is identifying the source of the material that the company will send. Make is the process of supply chain itself. Lastly, Deliver and Return are the process to dispatch the goods to the consumer and make a return in case something bad happened.

B. Data Collection and Processing Phase

The second phase is observing the entire business process in the supply chain of PT XYZ and collect the data. Then, identify risk events and risk agents based on the supply chain business process of PT XYZ. Measurement of risk events and risk severity is carried out using 
questionnaires to every identified risk agent. After that, calculating risk potential aggregate (ARP) to obtain the priority of risk agent.

C. Analysis and discussion phase

The third phase is analyzed and discuss the observation that already happen in the previous phase. Analyzing the result of HOR with top management and also selected stakeholder to see the greatest risk that influence supply chain business process. This phase is done many times until we can get the summary of every stakeholder and then draw it in Pareto Diagram to identify the most influence risk during the supply chain business process.

D. Withdrawal Stage Conclusion

The last phase is a withdrawal stage conclusion to make a formulation of problems and objective that have been set on the research. After knowing which risk that has most influence in the process, managerial implications must be made to make a preventive solution to minimize the risk.

\section{Result and Discussion}

Supply chain is a long process of the journey from raw material until finished goods and deliver to the customer. A vending machine has a short supply chain compared to other manufacture goods, for example foods or clothes, but vending machine is a perishable goods and have a high maintenance. In Indonesia, where the vending machine itself is still uncommon, XYZ company has a strong market leader and also holds the supply chain itself. The difficulties come from the machine handling from the factory until deliverit to the costumer. The comparation of the number technician and the machine that spread in the area of Jakarta, Depok, Bogor and Bekasi is very high, it's 1 technician for 20 machines. Knowing the risk is quitehigh that's make the reason of this study is being held. House of Risk is one of the tools to observe and identify the most common risk in XYZ company and in the further study it can be used to make an investigation of the risk. The result of HOR phase one will be explained below:

1. Collecting SCOR Vending Machine Products

Data collection related to the business process of SCOR (Supply Chain operations chain) obtained through interviews with business owners who is expert in supply chain process business. Plan is identifying plan process of supply chain business process by mapping the sub-process one by one. Source is identifying the source of every business process to track the risk source if it's necessary. Make is mapping the activities in every supply chain business process. Deliver is knowing the logistic activities in vending machine company. The last is Return is identify after sales service as part of supply chain business process. All of these five businesses process identified by focused group discussion by 3 people, 2 business owners and 1 commissioner to validate the supply chain business process in order to mapping the potential risk in the company. The results of the SCOR business process can be seen in the following table 
Table 1. SCOR Bussiness Process PT XYZ

\begin{tabular}{|c|c|}
\hline $\begin{array}{l}\text { Business Prosess } \\
\text { (SCOR) }\end{array}$ & Sub Proses Supply Chain Management \\
\hline \multirow{5}{*}{ Plan } & Enclosure Production \\
\hline & Planning-Back End / System \& Application \\
\hline & Software Development \\
\hline & Site Acquisition \& Services Partnership \\
\hline & Funding \\
\hline \multirow[b]{2}{*}{ Source } & Procurement Components \& Material \\
\hline & $\begin{array}{l}\text { Procurement Card, Printer Paper, ATK, Office Supplies, } \\
\text { Etc. }\end{array}$ \\
\hline \multirow{4}{*}{ Make } & Assembling \\
\hline & System Activation \\
\hline & Design \& Prototyping -- Front End / Prototype VM \\
\hline & Testing System (SIT \& UAT) \\
\hline \multirow{6}{*}{ Deliver } & Handover Vending Machine \\
\hline & Deployment \\
\hline & Sales Activities \\
\hline & Card Management \\
\hline & Collection \\
\hline & Financial Expenditure \\
\hline \multirow{5}{*}{ Return } & Requirement \\
\hline & Operational \& Maintenance \\
\hline & Regular Maintenance \\
\hline & Repair Center \\
\hline & Customer Service \\
\hline
\end{tabular}

2. Mapping Risk Identification and Risk Agent

After knowing all the supply chain business process with SCOR method, the following step is by mapping the risk identification and risk agent. Risk identification is determining risk in every activity that could potentially lead to major damage, this include by checking the document and communicating the concern. While risk agent is an authorized person who is responsible to respond and handle the risk. The process is conducted by interview and questionnaire with each person in alldepartments of XYZ company, such as production department, system development department, software development department, commercial and financing department, and also procurement $\&$ inventory department. There are 94 risk event identification with accompanied by 94 risk agents in the entire company of XYZ.

\section{a. Identifying Risk Evaluation and Risk Agent}

Furthermore, after knowing the risk identification and risk agent, now evaluating the risk by assess the severity and occurrence level of each risk. Also assessing the correlation between risk event and risk agent to know the relation. Severity and occurrence are measuring how much the damage and the impact that can cause by the identification risk. Respondent will be asked filling the Linkertscale from 1 to 10,1 to non-damage and zero impact and 10 to very severe damage with a great impact. 


\section{b. House of Risk Analysis}

Now that all the questionnaire to identify the risk, the result of the questionnaire will be transformed in House of Risk Analysis (HOR) that indicates the Aggregate Risk Potential (ARP) value rating of each risk. From the formula it is know that the highest ARP is a risk with A74 code which is, a less capable antivirus system for poor monitoring and controlling the company. This risk considers as thehighest ARP risk because vending machine is depending not only the hardware but also the software that control the system of vending machine. While eligible technician is very limited and the progressof system software for the vending machine is quite fast, sometimes the company itself cannot controlthe computer virus. The following table is 10 risks with the highest ARP value.

Table 2. The 10 Greatest from HOR Results

\begin{tabular}{|l|l|l|}
\hline Kode & \multicolumn{1}{|c|}{ Risk Identification } & Value ARP \\
\hline A74 & $\begin{array}{l}\text { A less capable antivirus system, for poor monitoring and controlling of the } \\
\text { company. }\end{array}$ & 900 \\
\hline A91 & No local stock of slow-moving parts. & 729 \\
\hline A41 & Officers are less cautious in product repair process. & 540 \\
\hline A37 & No specific testing for the user interface. & 450 \\
\hline A70 & Lack of product socialization offered to the user. & 450 \\
\hline A16 & Some software features program out of scope. & 405 \\
\hline A18 & Lack of programmer Resources in the company & 405 \\
\hline A49 & Error making guidelines \& SOP against the use of vending machine. & 378 \\
\hline A15 & No tight deadlines are given in the work of software programs. & 360 \\
\hline A83 & User does not read the guidelines regarding the money conditions used. & 324 \\
\hline
\end{tabular}

\section{c. Pareto Diagram}

Based on the Pareto diagram below shows the cause of risk with the largest aggregate value is A74, which is less capable antivirus system, and poor monitoring and controlling of the company. A74 risk occurs because the security system is exposed to hacking or virus attack. Other risk causes are A91 where there is no local stock of slow-moving parts. Furthermore, the cause of risk A41 is the officer less cautious in the process of repairing the product into a risk agent with the third largest ARP number. Overall, there are 35 risk agents that are a priority risk agent for the company. 
Figure 2 Pareto Diagram

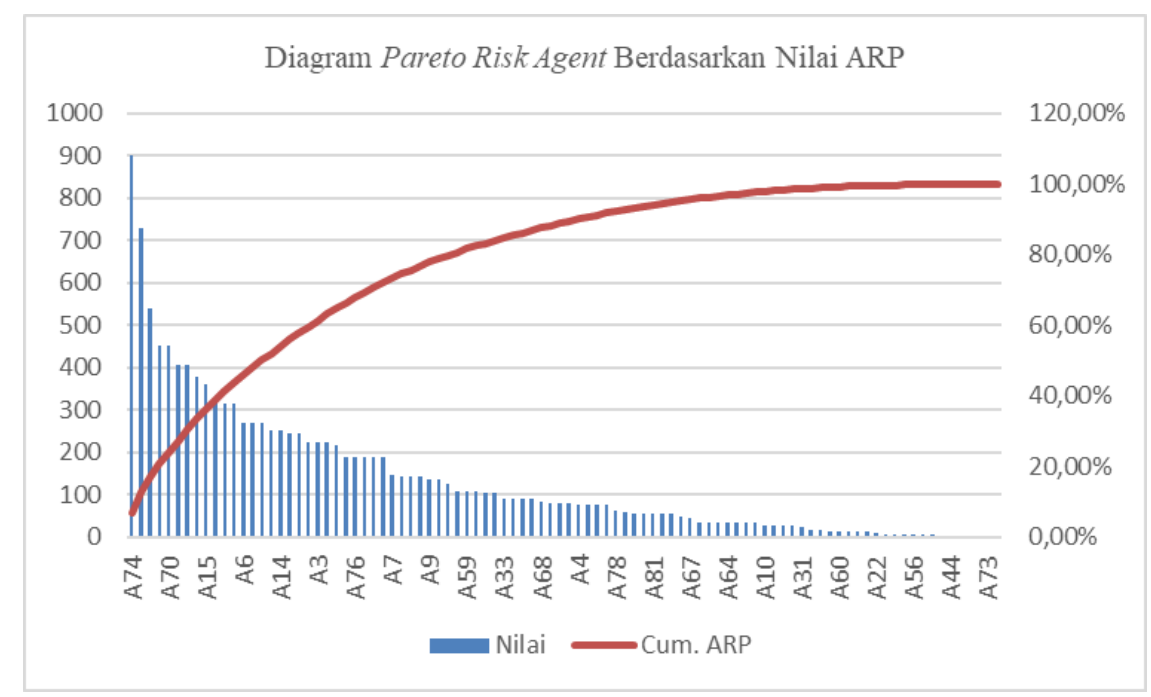

\section{Conclusion}

Based on the results data collection and processing and analysis using the House of Risk method, it can be concluded that House of Risk Phase 1 has been identified as 94 risks and 94 causes risk on the supply chain activity vending machine at PT XYZ. After the ARP calculation process in HOR Phase 1, Pareto diagram is conducted and selected 35 causes of risk prioritized to be mitigated on the supply chain of the vending machine at PT XYZ. The results of this research can be a suggestion for PT XYZ to pay attention to any risk that may have a big impact for the company. The researcher's suggestion is to proceedat the next stage of HOR Phase 2 so that it can get appropriate priority mitigation.

\section{References}

Arif, M. (2018). Supply Chain Management. Sleman: Deepublish.

Fan, Y., \& Stevenson, M. (2018). A review of supply chain risk management: definition, theory, and research agenda. International Journal of Physical Distribution \& Logistics Management.

Knolmayer, G. F., Mertens, P., Zeier, A., \& Dickersbach, J. T. (2009). Supply Chain Management Based on SAP Systems Architecture and Planning Processes. Berlin: Springer.

Lipovetsky, S. (2009). Pareto 80/20 law: derivation via random partitioning. International Journal of Mathematical Education in Science and Technology, 40(2),, 271-277.

Oguzhan, K., \& Erol, S. (2017). A Proactive Approach to Supply Chain Risk Management: Shifting Orders Among Suppliers To Mitigate The Supply Side Risks. Journal Of Purchasing \& Supply Management, 23, 54-65.

Pujawan, I. N., \& Geraldin, L. H. (2009). House of risk: a model for prosctive supply chain risk management. Business Process Management Journal, 953-967.

Sokovic, M., Pavletic, D., \& Fakin, S. (2005). Application of Six Sigma methodology for process design. Journal of Materials Processing Technology, 162-163, 777-783. 
Tang, O., \& Musa, S. N. (2011). Identifying risk issues and research advancements in supply chain risk management. International Journal of Production Economics, 25-34.

Wagner, S., \& Bode, C. (2009). Dominant risks and risk management practices in supply chains. Supply Chain Risk: A Handbook of Assessment, Management and Performance. New York: Springer, 271290.

Yap, P. (2017). Panduan Praktis Manajemen Risiko Perusahaan. Jakarta: Growing Publishing. 